\title{
Efficacy of Chitosan as a Dry Dressing for Treatment of Open Hoof Wounds
}

\author{
Ahmed Mohamed Abdou ${ }^{1 *}$, Azab, Abdelnaser Abdelmoneim ${ }^{1}$ \\ and Soliman, Ahmed Sayed ${ }^{2}$ \\ ${ }^{1}$ Department of Surgery, Anesthesiology, and Radiology, Faculty of Veterinary Medicine, \\ South Valley University, Qena 83523, Egypt \\ ${ }^{2}$ Department of Surgery, Anesthesiology, and Radiology, Faculty of Veterinary Medicine, \\ Cairo University, Cairo 11865, Egypt \\ *Corresponding author
}

\section{A B S T R A C T}

This study was conducted to compare the repair efficacy of chitosan application on hoof lesions with the conventional treatment materials, regarding the aspects of clinical, radiographical and hematological findings. The puncture hoof wounds including hoof abscess are the main cause of lameness in equine and due to the difficulties of wound contraction and the incidence of infection, the wound healing is retarded. Chitosan is one of the biomaterials which was tested for experimental hoof

\section{Keywords}

Chitosan; Equine;

Hoof Abscess; Lameness

Article Info

\section{Accepted:}

12 March 2021

Available Online:

10 April 2021 lesions and proved as an excellent dry dressing, so we are trying to prove its efficacy in clinical cases adding more dimensions as its efficacy on reduction of pain time produced by hoof lesions considering that animal admitted to the study are working equines and the only source of income for its owners so it has no enough resting period. The study was applied on 41 equine Their age ranged from $(3-11)$ years which admitted to Brook hospital at Aswan city- Egypt and were assigned randomly into two groups; Treatment group (17 male donkeys, 2 female donkeys and 2 male horses) had a Chitosan topical application on days 1,3, and 7 then one time/week; The control group (16 male donkeys, 2 female donkeys, 1 male horse and 1 female horse) had the conventional treatment every two days. Venous blood sample were collected from all animals and assessed for the progress of clinical symptoms and healing stage. Based upon clinical and radiographical findings, hoof repair in chitosan treated group was faster than the control group in regard to the alleviation of pain intensity through tracking in lameness grading as well as its rapid control of exudate, connective tissue formation, and complete cornification of the horny defects in hooves. Hematological findings showed a significant increase in the platelets count in the chitosan-treated group which explains its control of bleeding.

\section{Introduction}

Anatomically, the equine hoof is a complex structure as it contains of the 3rd phalanx and the distal aspect of the 2nd phalanx the distal sesamoid bone, the hoof cartilage, Podotrochlear bursa (navicular bursa), the extensor and deep digital flexor tendon, and 
the others soft tissue structures. All of the hoof contents were enclosed in horny capsule (Constantinescu and Constantinescu, 2013, Grundmann et al., 2015).

Hoof injuries are the most common equine affections. Some wounds can charge diagnostic and treatment challenges because of the rigid nature of horn, the involved tissue, or the healing pattern (Christophe and Mihaly, 2005).

The puncture foot wounds are categorized into superficial or deep wounds depending on depth, direction, and location of wounds. In the superficial wounds, only the cornified tissue was affected. While in deep wounds, the deeper contents of the hoof were affected like navicular bursa, digital cushion, digital flexor tendon sheath (DFTS), $3^{\text {rd }}$ phalanx, or distal interphalangeal joint due to the penetration of the hoof corium (Dabareiner and Carter, 2003). The degree of lameness may vary considerably depending on the depth, location, and duration of the wound (Abdel-Hady et al., 2017).

Wounds of the hoof generally, heal slowly due to the high incidence of contamination, difficulty in contraction of hoof wounds and inelasticity of epithelial tissue (Richardson and Pascoe, 1986).

Hoof abscesses are probably the most common cause of acute severe lameness in horses faced by veterinarians and farriers. Most affected horses show sudden, severe (acute) lameness, which ranged from unclear in the early stages to non-weight bearing. The puncture wounds of sole may lead to fracture or a septic pedal ostitis due to introduction of bacteria and debris toward the solar surface of the distal phalanx and produce (Redding and O'Grady, 2012).

Chitosan is a natural biopolymer material that derived from chitin, which known by its haemostatic action, effects on macrophage and also it faster wound healing. Chitin is obtained from the outer skeletons of crustacean (Paul and Sharma, 2004, Balassa and Prudden, 1978).

Chitosan is an excellent dry dressing materials for treatment of open hoof wounds as it stop bleeding, prevent wetting, relieve the intensity of pain, reduce the risk of contamination and enhance the regeneration and cornification of the hoof (Abou-El-Ella et al., 2007).

Chitosan enhance the function of inflammatory cells such as polymorph nuclear leukocytes, fibroblast, and macrophage so it promotes granulation and organization (Ishihara et al., 2002).

The Radiographic examination helps in the diagnosis and treatment of the hoof injuries as it considered the most applicable diagnostic imaging tool for the equine distal limb (AbdelHady et al., 2017).

\section{Materials and Methods}

\section{Ethical statement}

The experimental procedures were approved by the Ethical Committee of South Valley University, Qena, Egypt.

\section{Animals}

The present study was carried out on 41 animals which were divided into two groups as the following:

Control group: N=20 (16 male donkeys, 2 female donkeys, 1 male horse and 1 female horse).

Treated group: $\mathrm{N}=21$ (17 male donkeys, 2 female donkeys and 2 male horses).

The animal age was (ranged from 3 years to 11 years). These animals were admitted to 
Aswan clinic, Brooke hospital for animals from November 2017 to December 2019 suffering from hoof punctured wounds. Case history was taken concerning onset and duration of the diseases, clinical examination of the limb with identification of the lameness degrees according to lameness grading system developed by American Association for Equine Practitioners (AAEP) (Swanson, 1984).

Each animal was examined clinically and any abnormalities on the affected limb were taken in consideration.

Physical examination of the distal limb were done as the following according to (Baxter and Turner, 2002):

Complete history.

Visual examination of the animal at rest and in motion.

Palpation of the musculoskeletal system including hoof tester examination of the hoof.

Palpation of the limbs and axial skeleton and hoof tester examination of the feet are usually performed prior to exercising the animal.

\section{Drugs}

Chitosan ${ }^{\circledR}$ (Alpha Chemika Company, India).

Xyla-ject® (Adwia Company, Egypt) in a dose of $1.1 \mathrm{mg} / \mathrm{kg}$ used for sedation of the animals to remove all debris's and necrotic tissues.

Betadine ${ }^{\circledR}$ antiseptic (ElNail Co) used to disinfect lesion.

\section{Treatment protocol}

The control group was treated with betadine and the second group(treatment) was treated with chitosan. The penetrating wounds of the sole treated according to (Stashak, 2002) which include:

Keep region clean and protected until healing.

Following drainage, the wound cleaned with antiseptic solution.

The opening packed with Povidone iodine.

Foot bandaged thoroughly.

\section{Method of application Chitosan according to (Abou-El-Ella et al., 2007)}

One gm of chitosan was applied on the lesion on days 1, 3, 7 and then one time/ week (Fig. $1)$.

Application of chitosan was continued until full recovery.

The wounded area was covered with nonadherent occlusive cotton bad (Fig. 2).

Hoof protected by bandage after dressing.

\section{Radiographic examination}

There were two cases with foreign body penetration from each group which were examined radiographically before application of treatment and after absence of all clinical signs using of different radiographic projection by using Agfa computed radiography (CR) and Atomscope - 1000PR apparatuses.

\section{Hematological parameters}

\section{Blood sampling}

Blood samples were collected from all animals in both groups from jugular vein puncture at days 1, 3 and 7.using EDTA coated collecting tube. 
Fig.1 Method of application of Chitosan

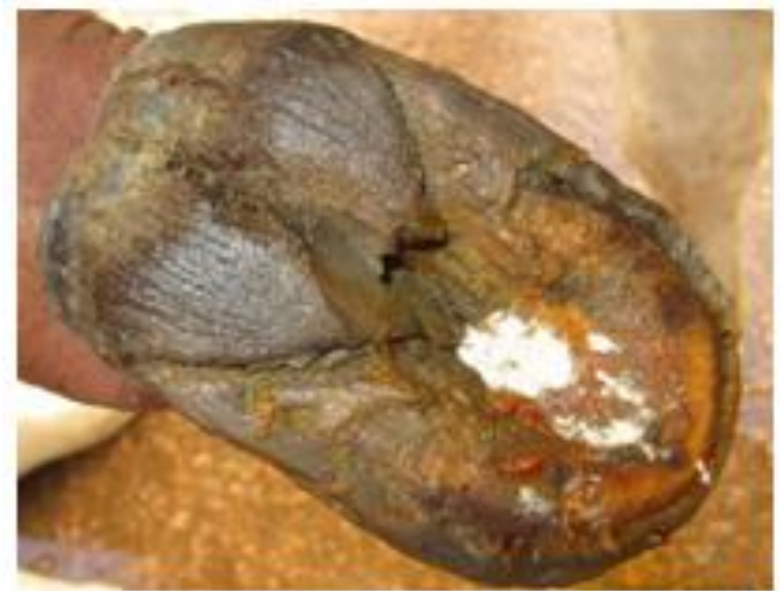

Sample sent and analyzed by Aswan vet. collage lab, using a complete blood count (CBC) machine.

Plattelets was counted on both groups of animals at days 1,3 and 7

\section{Healing parameters}

Using a scoring system to capture the progress of healing according to (Abou-el-Ella, et al., 2007).

Score 0: means presence of thick compact layers of coagulated blood that seal the sole wound.

Score1: wound completely filled with granulation tissue.

Score2: presence of focal area of cornification invades the granulation tissue.

Score3: cornification become numerous and thicker at peripheral area.

Score4: a thin layer of cornified tissue covering the whole wound.

Score5: the thickness of newly formed horny materials progressed.
Fig.2 Bandaging after treatment application

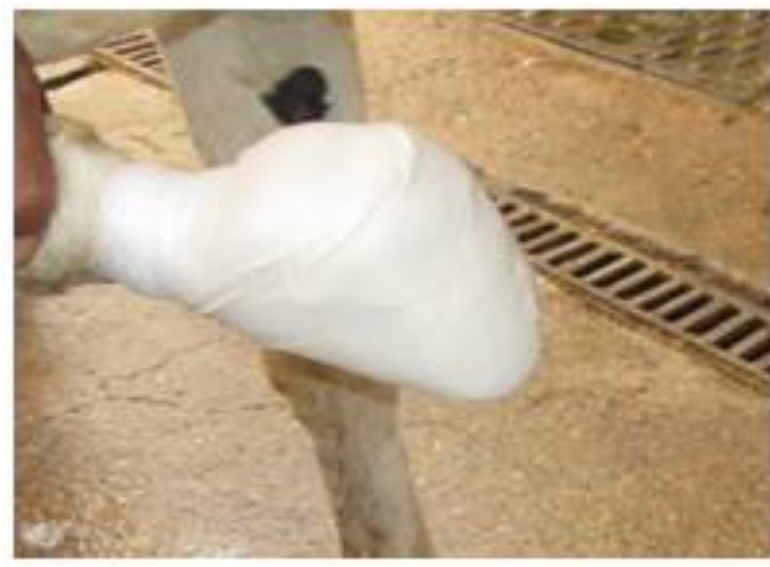

\section{Lameness grading scores (AAEP) (Swanson, 1984)}

Grad 0: lameness imperceptible under any circumstances.

Grad 1: lameness difficult to observe, not consistently apparent regardless of circumstances e.g. Weight carrying, circling, inclines, hard surface.

Grad 2: lameness difficult to observe at walk or trot in straight line, consistently apparent under some circumstances (e.g. weight, circling, inclines, and hard surface).

Grad 3: lameness consistently observable at a trot under all circumstances.

Grad 4: obvious lameness, marked nodding, hitching and or short stride.

Grad 5: obvious lameness, minimal weight bearing in motion or rest, inability to move.

\section{Data analysis and report format}

Data was analyzed by SPSS using independent T test. 


\section{Results and Discussion}

\section{Clinical findings}

\section{Exudates:}

\section{Bleeding}

Bleeding: was obviously seen after debridement of dead and necrotic tissues of infected hooves in both groups (Fig 3) and stopped spontaneously in all chitosan treated group of equines after three days of treatment. A thick compact layer was formed (Fig.4) that

Fig.3 Bleeding after debridement

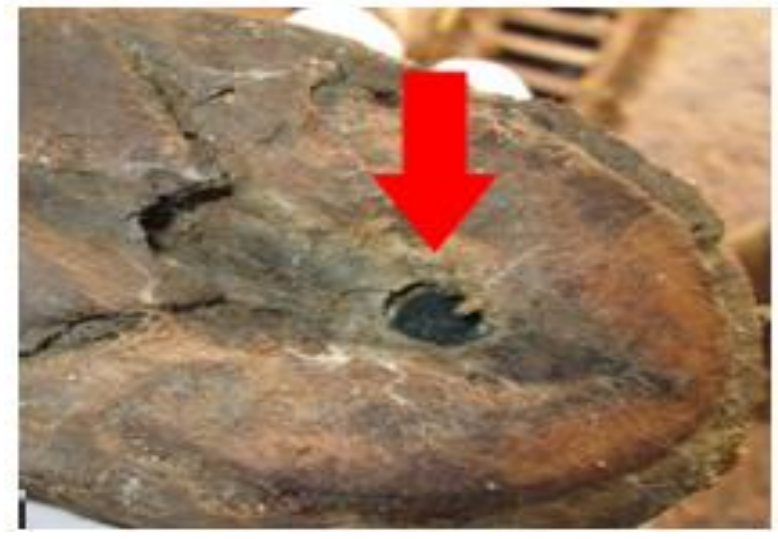

Fig.5 Pus exudates

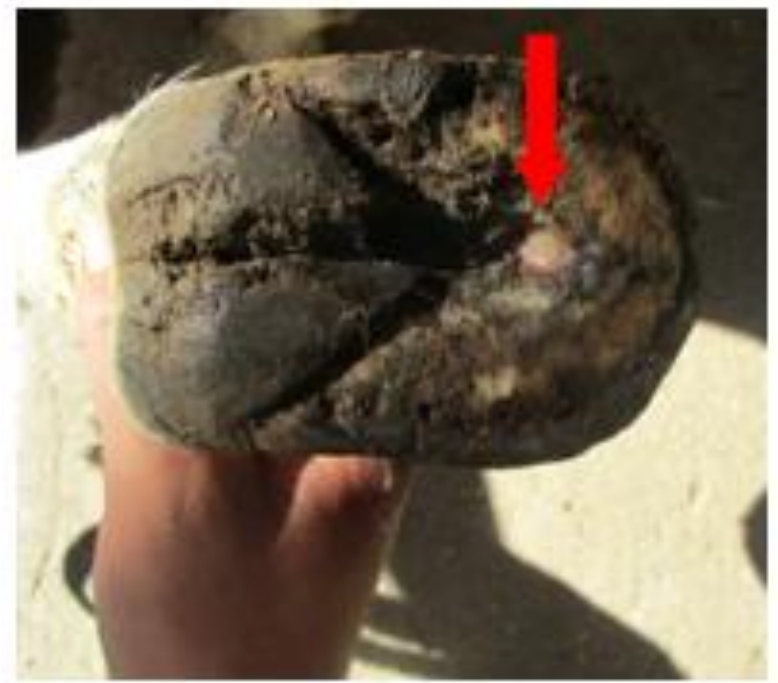

completely sealed the lesion (score 0), while bleeding continue for more than a week in control group of animagysls where blood oozing still present during the dressing.

\section{Pus discharge}

6 cases in both groups 3 in both were infected and showed pus discharge (Fig5). while all treated animals showed no pus exudates (Fig6) after three days of chitosan application it took up to two weeks in control group of animals to show no pus discharge.

Fig.4 Thick compact layer

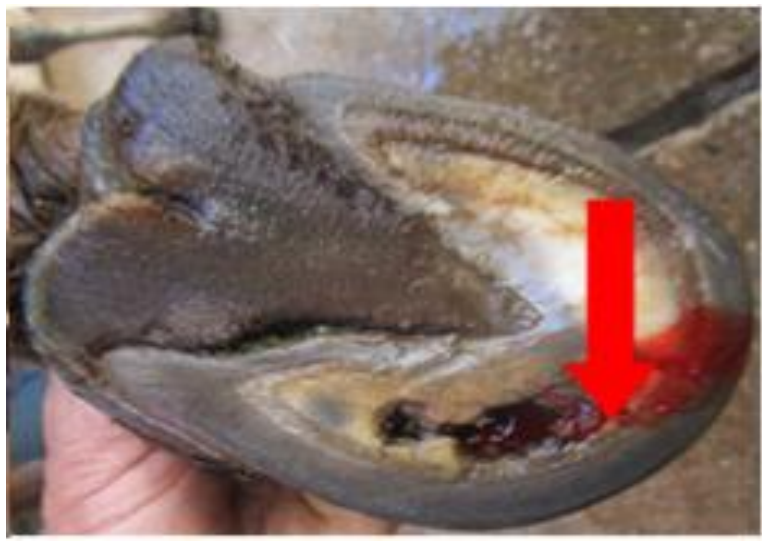

Fig.6 No pus exudates

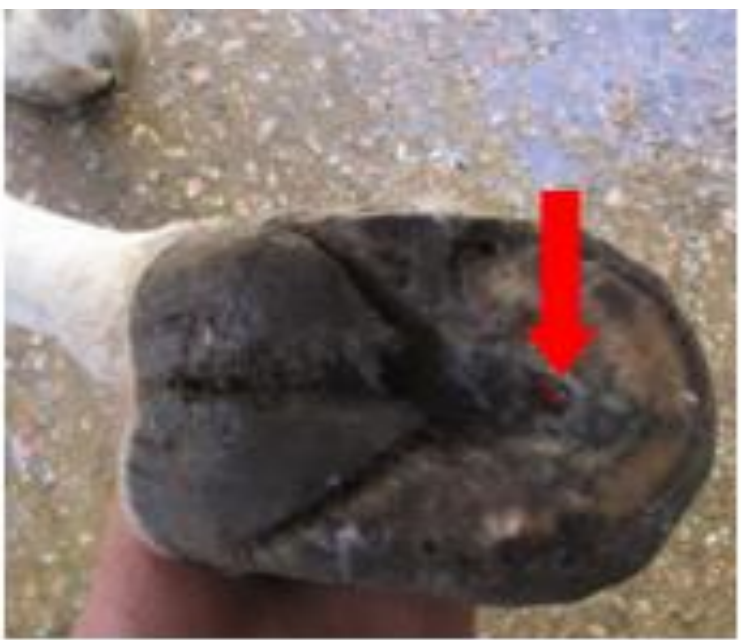




\section{Lameness}

(Table. 1) shows the progress in lameness grade, there were three cases in Chitosan group showed score 1 after one week. While it lasts to three weeks in control group of animals to show score one or zero. The good result was observed in chitosan treated working equine. After three weeks, 18 out of 21 cases were showed lameness score one or zero which allowed them to return work with special consideration (dressing weekly). While in control group just 4 out of 20 cases showed the same result after three weeks and they dressed every two days.

Regarding to healing stages on both control and treated animal groups, the following criteria were noticed:

\section{Wound filled with granulation tissue}

In chitosan treated group, all lesions were completely filled with granulation tissues (Fig.7a and 7b) with a different timeline.

Four cases show granulation tissues completely and filled the lesion within the first week of chitosan application while the rest of the treated cases show granulation tissue by the end of the second week.

In case of control group, the lesions completely filled with granulation tissue after 3 weeks in 4 cases; after 4 weeks in 6 cases; after 5 weeks in 8 cases and after 6 weeks in two cases.

Presence of focal area of cornification invades the granulation tissue

Both groups showed focal area of cornification (Fig. 8a and 8b) invaded the granulation tissue within a week after the lesion completely filled with granulation tissues.
Cornification become numerous and thicker at peripheral area

The cornification appeared numerous and thicker at peripheral area (Fig.9a and 9b) within one week after presence of focal area of cornification in chitosan treated group. While these formed from two to three weeks in control group.

\section{Thin layer of cornified tissue covering the whole wound}

It was seen after 5 weeks in chitosan treated group (Fig.10a and 10b). While, in control group the thin layer of cornification started in 6 cases after 8 weeks; 6 cases after 9 weeks; two cases after 10 weeks; 4 cases after 11 weeks; two cases after 12 weeks from starting conventional treatment.

The thickness of newly formed horny materials progressed

After chitosan application showed the formation of newly formed horny materials in different timeline (Fig11a and 11b), as it started in three cases after 11 weeks and in most cases (fourteen animals) after 12 weeks and three cases after 13 weeks and one case with picked up nail that penetrate the $3^{\text {rd }}$ phalanges took 32 weeks to return to work, The animals of control group also showed the newly formed horny materials in different timeline, as it started in four cases after 18 weeks from application of conventional treatment and four cases showed it after 19 weeks and two cases after 20 weeks and four cases after 21 weeks and two cases after 22 weeks and four cases after 23 weeks.

\section{Radiographic Examination}

From the radiographic examination it was observed that, lateromedial, palmarodorsal views were the best for examination of hoof injuries. The cases admitted to Brooke 
hospital suffered from injuries of the hoof from introduction of foreign body which was diagnosed radiographically and leads to wound at the penetration site, or abscess formation which make suppuration and lysis of the horny material of hoof and/or the distal phalanx and cause its suppuration. There were two cases in each group which suffered from penetration of foreign body (picked up nail). Radiographic examination of cases conducted at admitted time and after absence of clinical signs.

Fig.7a, 7b Lesion filled with granulation tissues

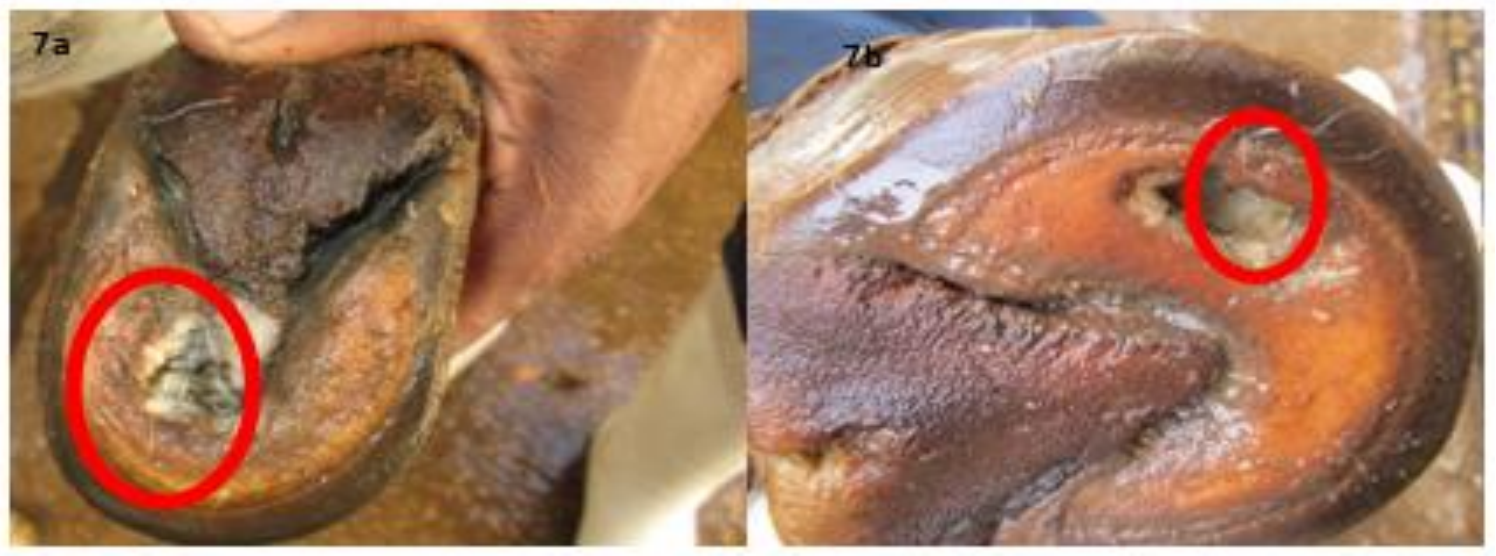

Fig.8a, 8b Focal area of cornification
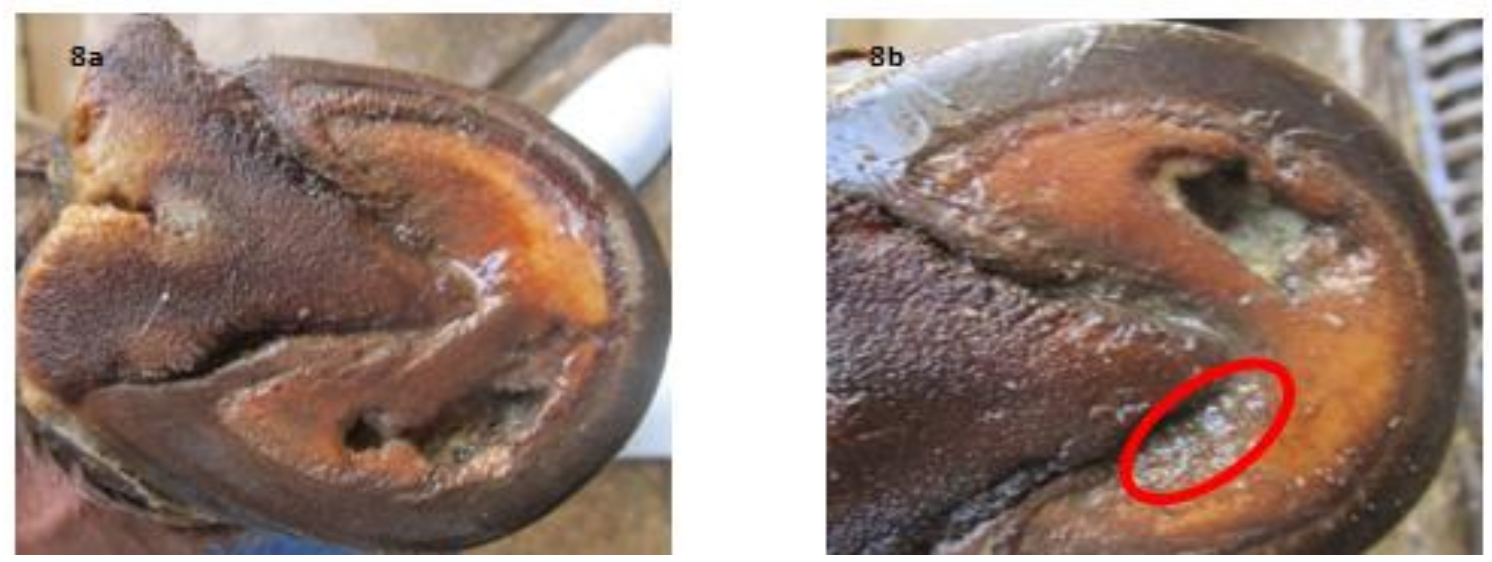
Fig.9a, 9b Cornification become numerous and thicker at peripheral area

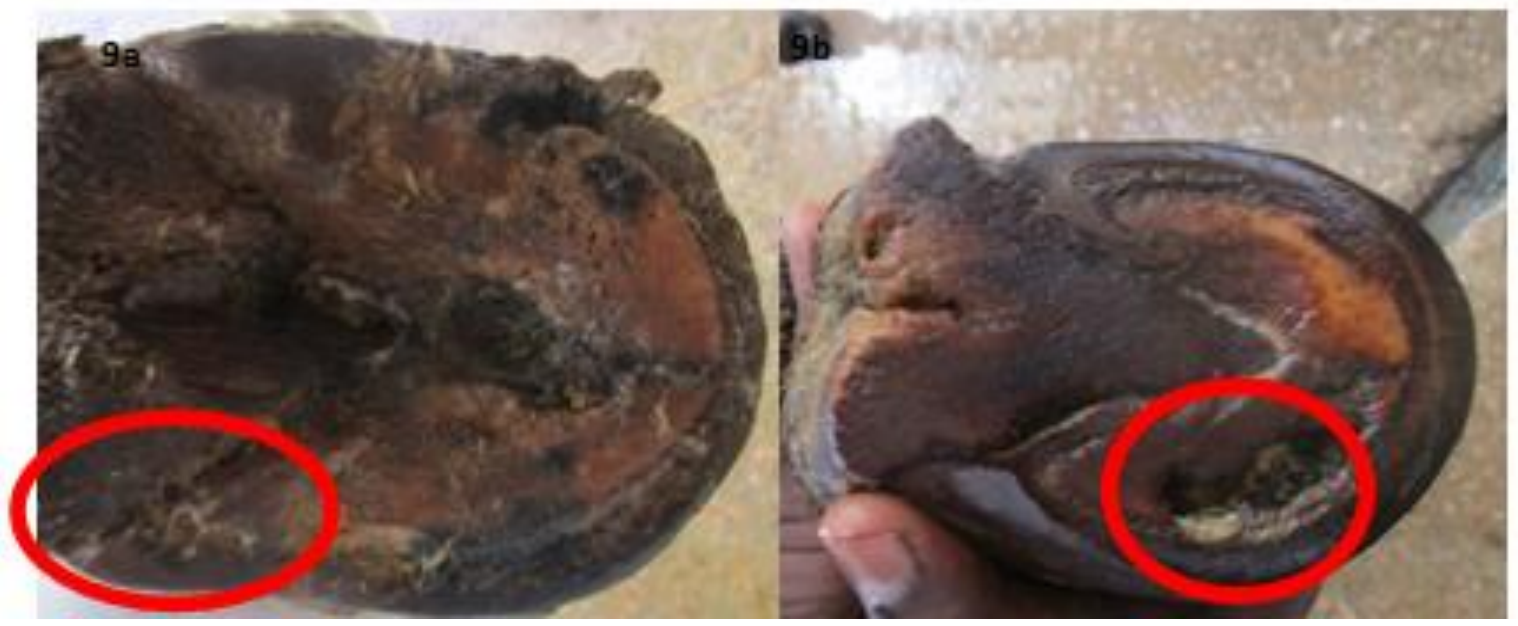

Fig.10a, 10b Thin layer of cornification cover the whole lesion.

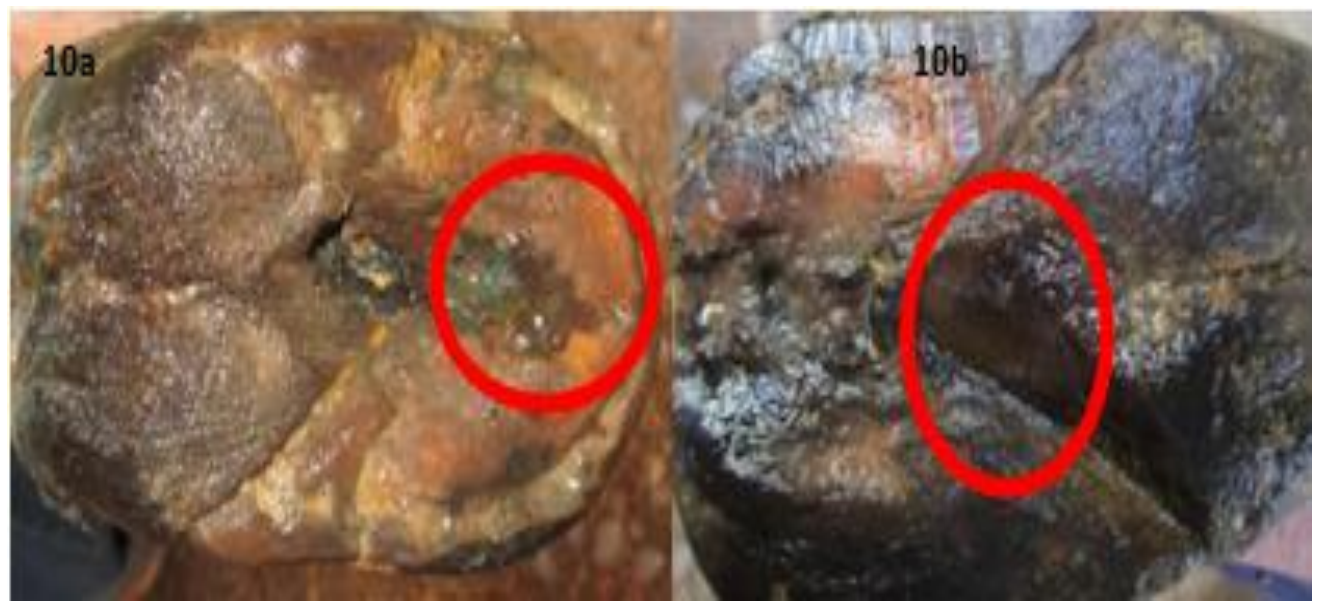

Fig.11a, 11b Thickness of newly formed horny materials progressed.
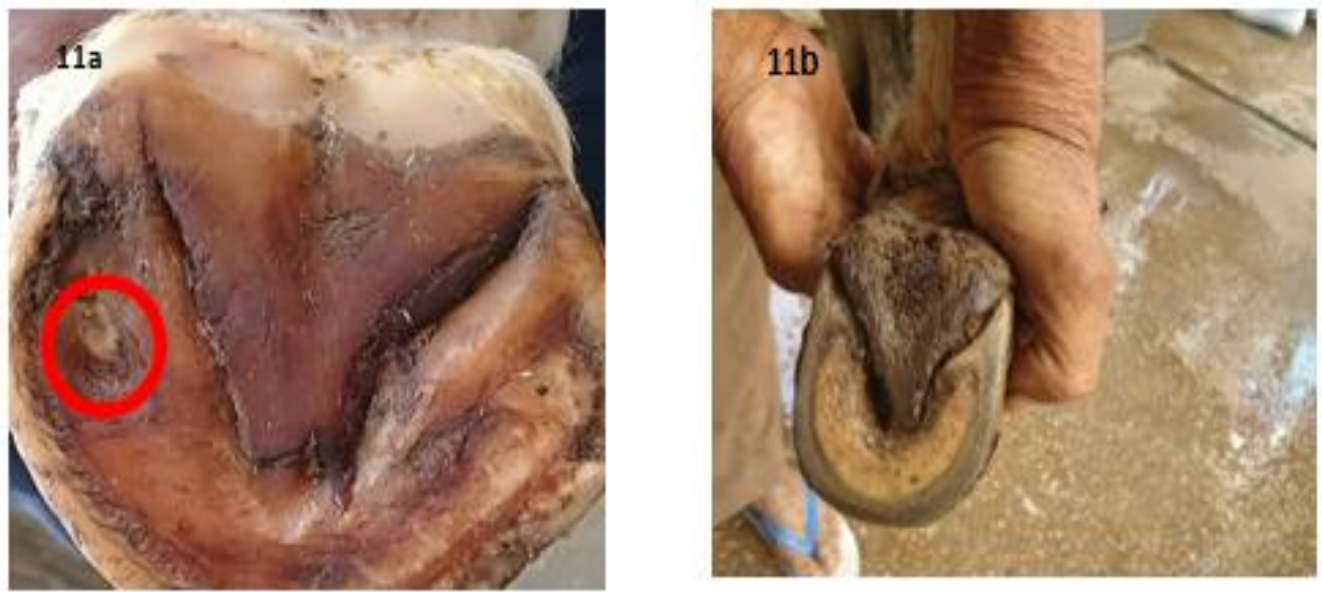
Chitosan treated animals showed full internal structure density formation after 4 and 5 weeks (Fig $14 \& 15$ ). While animals treated with povidone iodine showed no change in one case examined after 34 weeks and one case with appearance of the normal radiographic densities of the tissues after 32 weeks (Fig $12 \& 13$ ).

Fig.12 A) Lateromedial view of the hoof of the forelimb of 5years old horse showing penetration of the foreign body into the hoof (arrow); B) Lateromedial oblique view of the same case showing the introduced foreign body (arrow) which leave wound after its removal; C) Mediolateral view of the same case after removal of the nail and treatment with conventional treatment for 32 weeks showing complete healing of the wound with the appearance of the normal radiographic densities of the tissuest animal then returned to work.
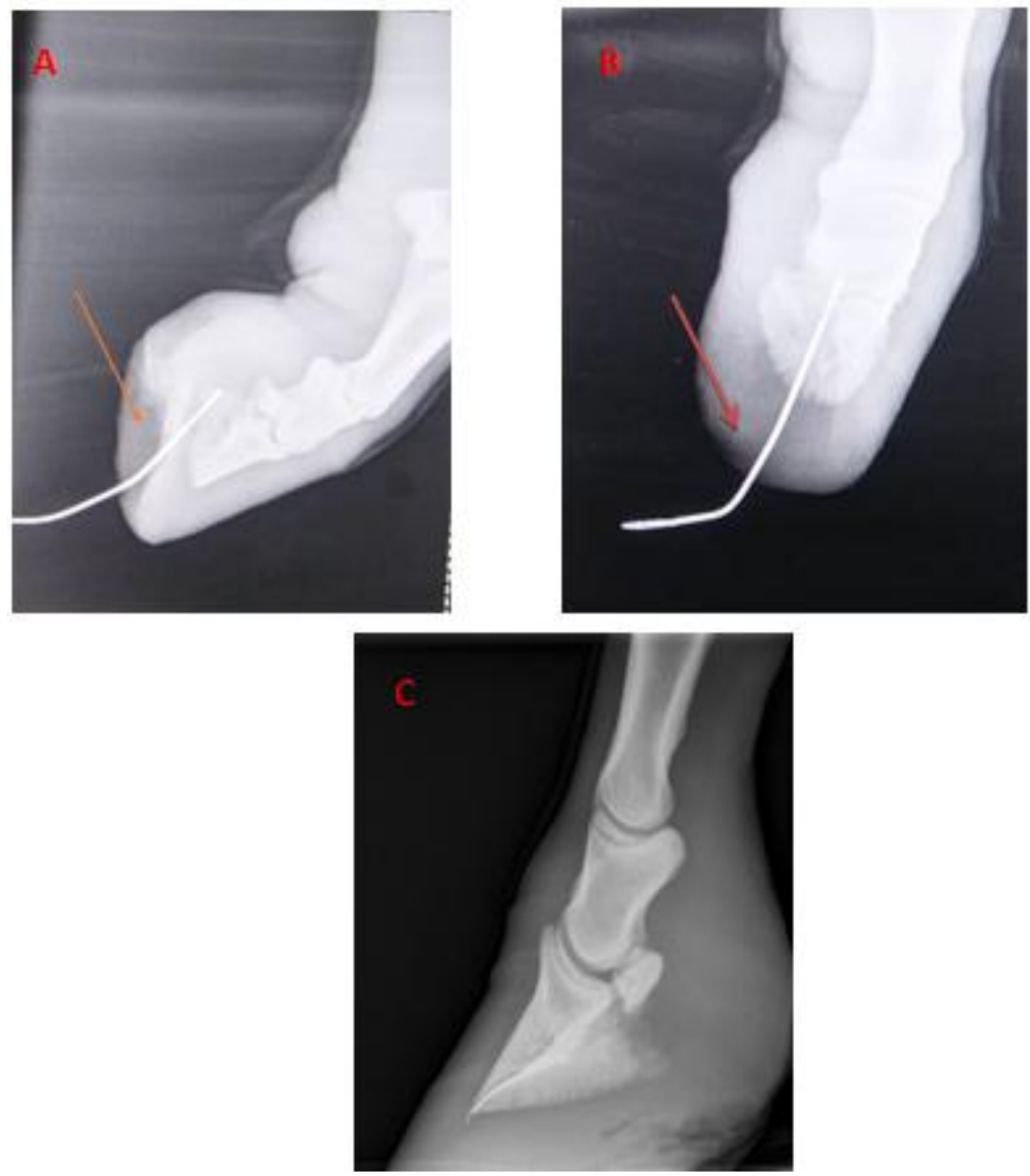
Fig.13 A) Dorsoplantar view of the hoof of hind limb of 8 years old donkey showing lysis of the hoof horny tissues; B) Dorsoplantar view of the same hoof showing no change after 4 weeks from povidone-iodine treatment

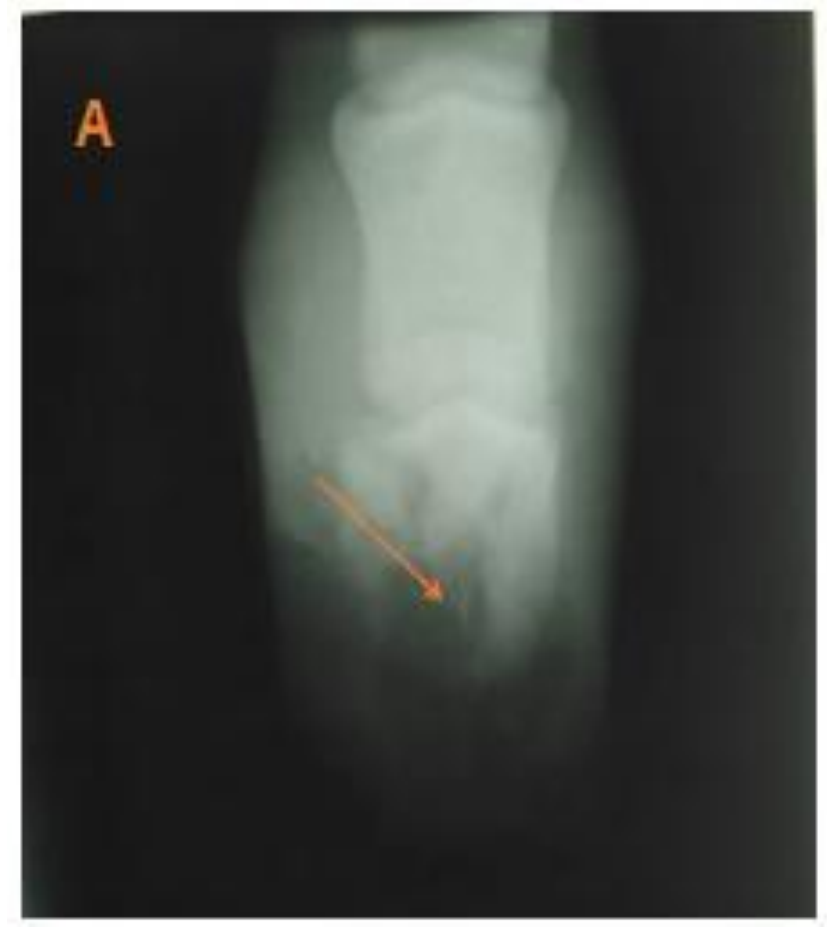

\section{Hematological findings}

CBC was done for each animal on both groups to capture the platelets (PLT) count as well as the other hematological parameters. Results for treatment group were illustrated in (table 2) comparing values of hematological parameters in day 1 and day 3 and (table 4) comparing values of hematological parameters in day 1 and day 7 which showed significance increase in PLT

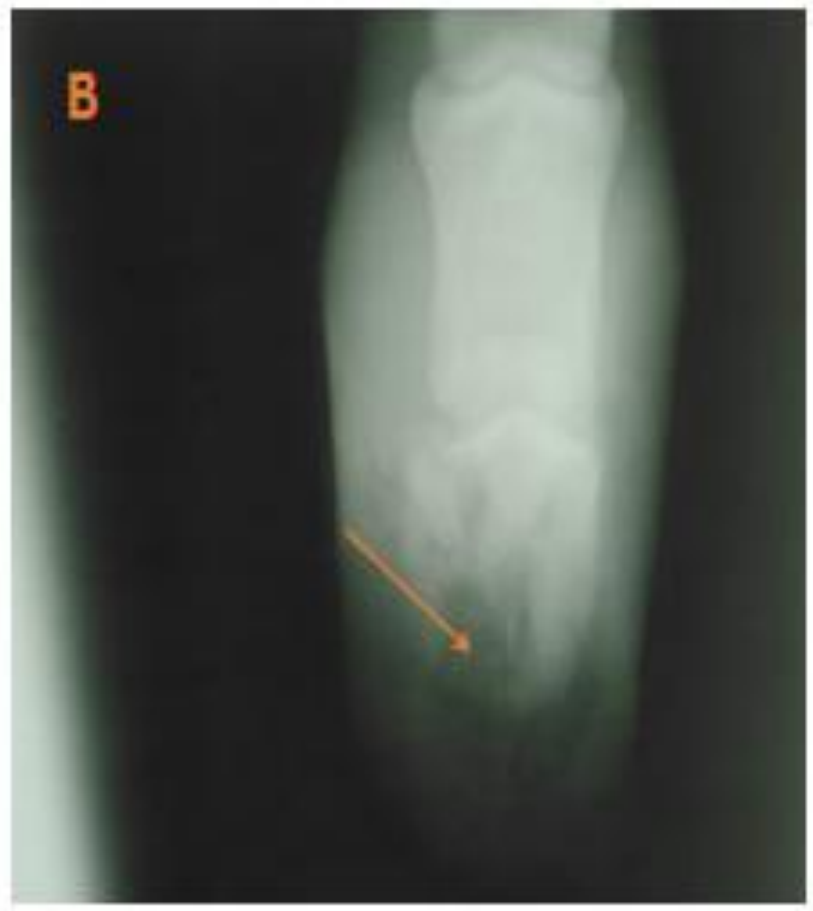

in animals treated by chitosan and that explain the good result of stop bleeding on treatment group of animals. Other parameters showed no significance differences. Results of control group were illustrated in (table 3) comparing values of hematological parameters in day 1 and day 3 and (table 5) comparing values of hematological parameters in day 1 and day 7 showed no significance changes in any of the hematological parameters. 
Fig.14 A) Palmarodorsal view of the hoof of the forelimb of 11years old horse showing lysis of the hoof horny tissues and $3^{\text {rd }}$ phalanx as a result of hoof abscess (arrow); B) Palmarodorsal view of the same animal's hoof showing the normal radiographic densities of the hoof and $3^{\text {rd }}$ phalanx from 5 weeks of chitosan application (arrow); C) Lateromedial view of the hoof after chitosan treatment.
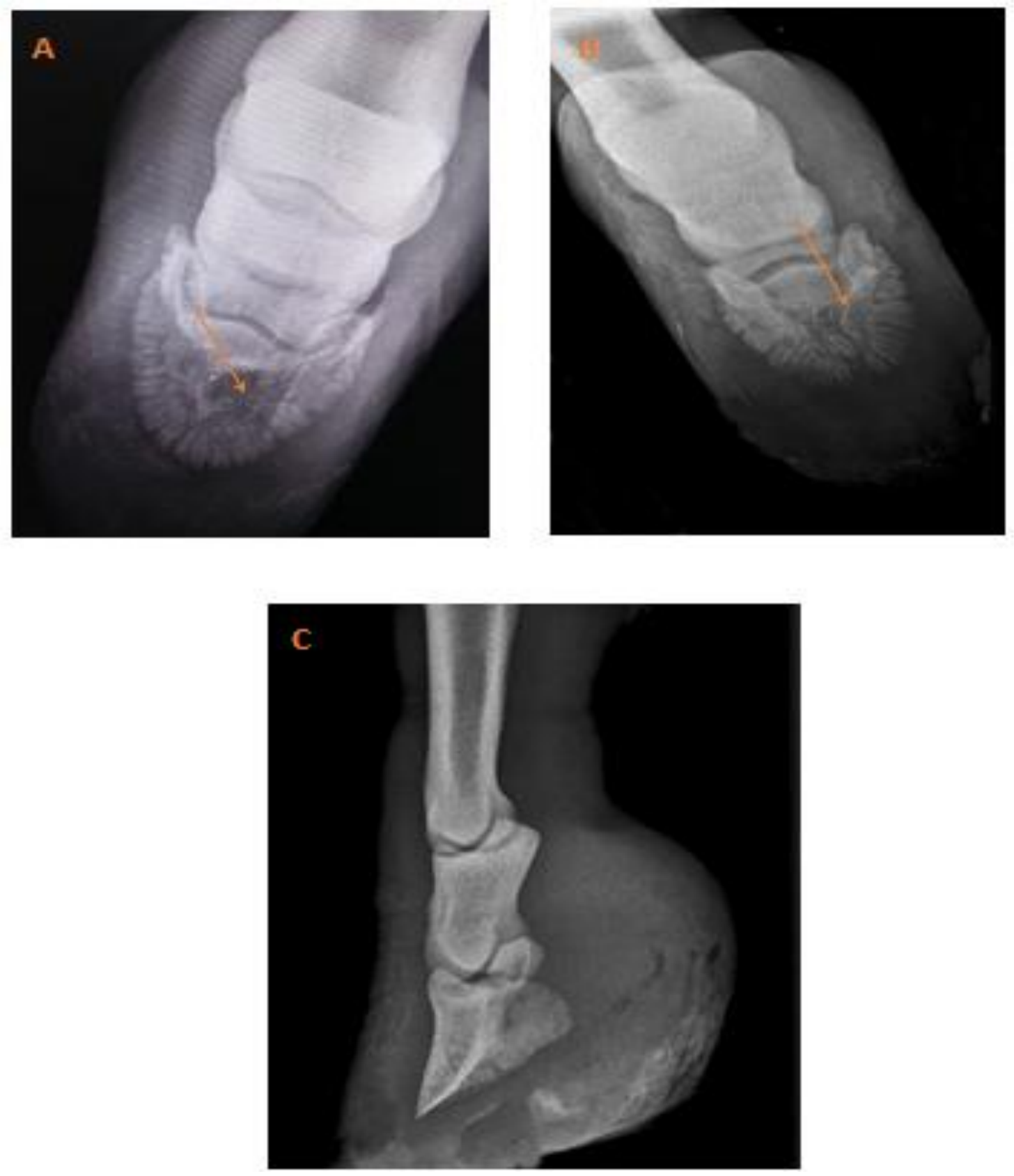
Fig.15 A) Palmarodorsal view of the hoof of the forelimb of 6years old donkey showing lysis of the horny tissues due to abscess formation (arrow); B) Palmarodorsal view of the same case showing the normal structure and radiographic densities of hoof after chitosan application by 4 weeks; C) Lateromedial view of the hoof after chitosan treatment.
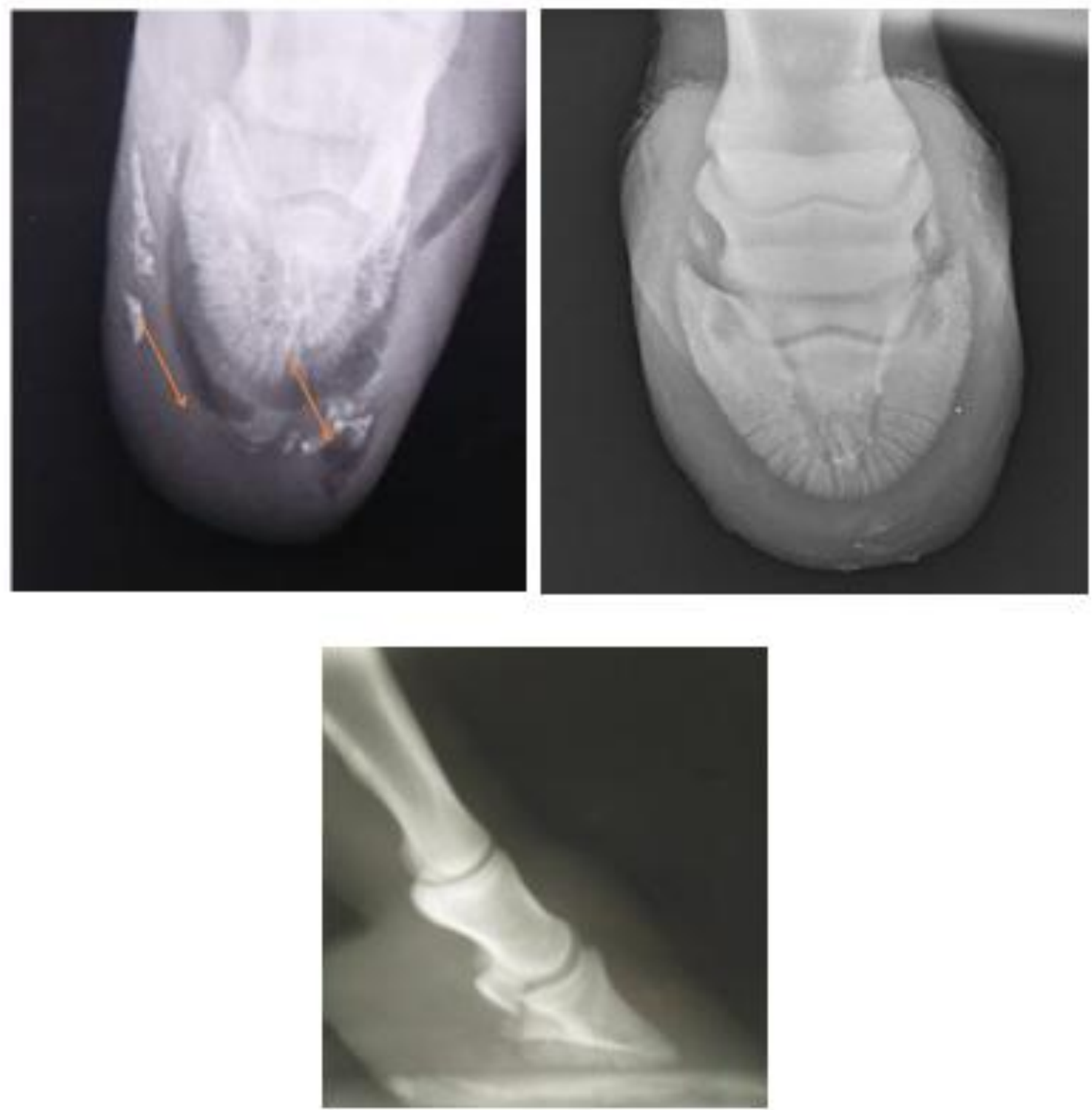


\section{Int.J.Curr.Microbiol.App.Sci (2021) 10(04): 84-102}

Table. 2 Comparing values of day 1 and day 3 treatment group Independent Samples Test

\begin{tabular}{|c|c|c|c|c|c|c|c|c|c|c|}
\hline & & \multicolumn{2}{|c|}{$\begin{array}{l}\text { Levene's } \\
\text { Test for } \\
\text { Equality of } \\
\text { Variances }\end{array}$} & \multicolumn{7}{|c|}{ t-test for Equality of Means } \\
\hline & & \multirow[t]{2}{*}{$\mathrm{F}$} & \multirow[t]{2}{*}{ Sig. } & \multirow[t]{2}{*}{$\mathrm{t}$} & \multirow[t]{2}{*}{ df } & \multirow{2}{*}{$\begin{array}{l}\text { Sig. }(2- \\
\text { tailed) }\end{array}$} & \multirow{2}{*}{$\begin{array}{c}\text { Mean } \\
\text { Difference }\end{array}$} & \multirow[t]{2}{*}{ Std. Error Difference } & \multicolumn{2}{|c|}{$\begin{array}{l}95 \% \text { Confidence Interval of } \\
\text { the Difference }\end{array}$} \\
\hline & & & & & & & & & Lower & Upper \\
\hline \multirow[b]{2}{*}{$\mathrm{MCHC}$} & Equal variances assumed & .312 & .580 & -.359 & 40 & .722 & -.43429 & 1.21096 & -2.88173 & 2.01316 \\
\hline & $\begin{array}{c}\text { Equal variances not } \\
\text { assumed }\end{array}$ & & & -.359 & 39.870 & .722 & -.43429 & 1.21096 & -2.88198 & 2.01341 \\
\hline \multirow[b]{2}{*}{$\mathrm{MCV}$} & Equal variances assumed & .529 & .471 & -.031 & 40 & .975 & -.04762 & 1.51245 & -3.10439 & 3.00916 \\
\hline & $\begin{array}{l}\text { Equal variances not } \\
\text { assumed }\end{array}$ & & & -.031 & 39.882 & .975 & -.04762 & 1.51245 & -3.10468 & 3.00944 \\
\hline \multirow[b]{2}{*}{$\mathrm{MCH}$} & Equal variances assumed & 1.329 & .256 & -.360 & 40 & .721 & -.31667 & .88030 & -2.09582 & 1.46248 \\
\hline & $\begin{array}{c}\text { Equal variances not } \\
\text { assumed }\end{array}$ & & & -.360 & 38.824 & .721 & -.31667 & .88030 & -2.09750 & 1.46416 \\
\hline \multirow[b]{2}{*}{ RBCS } & Equal variances assumed & .200 & .657 & .252 & 40 & .803 & .07048 & .28012 & -.49566 & .63661 \\
\hline & $\begin{array}{c}\text { Equal variances not } \\
\text { assumed }\end{array}$ & & & .252 & 39.983 & .803 & .07048 & .28012 & -.49567 & .63662 \\
\hline \multirow[b]{2}{*}{$\mathrm{HCT}$} & Equal variances assumed & .044 & .835 & .333 & 40 & .741 & .48619 & 1.45796 & -2.46047 & 3.43285 \\
\hline & $\begin{array}{c}\text { Equal variances not } \\
\text { assumed }\end{array}$ & & & .333 & 39.481 & .741 & .48619 & 1.45796 & -2.46167 & 3.43405 \\
\hline \multirow[b]{2}{*}{ HGB } & Equal variances assumed & .092 & .764 & .015 & 40 & .988 & .00476 & .31765 & -.63723 & .64675 \\
\hline & $\begin{array}{c}\text { Equal variances not } \\
\text { assumed }\end{array}$ & & & .015 & 39.778 & .988 & .00476 & .31765 & -.63734 & .64686 \\
\hline \multirow{2}{*}{ PLT } & Equal variances assumed & .746 & .393 & -2.473 & 40 & .018 & -36.42857 & 14.72932 & $\begin{array}{c}- \\
66.19764\end{array}$ & -6.65951 \\
\hline & $\begin{array}{c}\text { Equal variances not } \\
\text { assumed }\end{array}$ & & & -2.473 & 39.911 & .018 & -36.42857 & 14.72932 & $\begin{array}{c}- \\
66.19970\end{array}$ & -6.65744 \\
\hline
\end{tabular}

a. group of study $=$ treatment 
Table.3 Comparing values of day 1 and day 3 control group

\begin{tabular}{|c|c|c|c|c|c|c|c|c|c|c|}
\hline \multicolumn{11}{|c|}{ Independent Samples Test ${ }^{\text {a day } 1 \text { to day } 3}$} \\
\hline & & \multicolumn{2}{|c|}{$\begin{array}{l}\text { Levene's Test for Equality } \\
\text { of Variances }\end{array}$} & \multicolumn{7}{|c|}{ t-test for Equality of Means } \\
\hline & & \multirow[t]{2}{*}{$\mathrm{F}$} & \multirow[t]{2}{*}{ Sig. } & \multirow[t]{2}{*}{$\mathrm{t}$} & \multirow[t]{2}{*}{ df } & \multirow{2}{*}{$\begin{array}{l}\text { Sig. }(2- \\
\text { tailed) }\end{array}$} & \multirow{2}{*}{$\begin{array}{c}\text { Mean } \\
\text { Difference }\end{array}$} & \multirow{2}{*}{$\begin{array}{l}\text { Std. Error } \\
\text { Difference }\end{array}$} & \multicolumn{2}{|c|}{$\begin{array}{l}\text { 95\% Confidence Interval of the } \\
\text { Difference }\end{array}$} \\
\hline & & & & & & & & & Lower & Upper \\
\hline \multirow{2}{*}{$\mathrm{MCHC}$} & $\begin{array}{l}\text { Equal variances } \\
\text { assumed }\end{array}$ & .038 & .846 & -1.321 & 38 & .194 & -1.30850 & .99032 & -3.31330 & .69630 \\
\hline & $\begin{array}{c}\text { Equal variances not } \\
\text { assumed }\end{array}$ & & & -1.321 & 37.924 & .194 & -1.30850 & .99032 & -3.31343 & .69643 \\
\hline \multirow{2}{*}{ MCV } & $\begin{array}{c}\text { Equal variances } \\
\text { assumed }\end{array}$ & .049 & .826 & -.785 & 38 & .437 & -1.13000 & 1.43874 & -4.04257 & 1.78257 \\
\hline & $\begin{array}{l}\text { Equal variances not } \\
\text { assumed }\end{array}$ & & & -.785 & 37.962 & .437 & -1.13000 & 1.43874 & -4.04267 & 1.78267 \\
\hline \multirow{2}{*}{$\mathrm{MCH}$} & $\begin{array}{l}\text { Equal variances } \\
\text { assumed }\end{array}$ & 2.423 & .128 & -1.850 & 38 & .072 & -1.16500 & .62985 & -2.44006 & .11006 \\
\hline & $\begin{array}{l}\text { Equal variances not } \\
\text { assumed }\end{array}$ & & & -1.850 & 34.617 & .073 & -1.16500 & .62985 & -2.44417 & .11417 \\
\hline \multirow{2}{*}{ RBCS } & $\begin{array}{l}\text { Equal variances } \\
\text { assumed }\end{array}$ & 1.603 & .213 & 1.436 & 38 & .159 & .30800 & .21449 & -.12621 & .74221 \\
\hline & $\begin{array}{l}\text { Equal variances not } \\
\text { assumed }\end{array}$ & & & 1.436 & 35.405 & .160 & .30800 & .21449 & -.12725 & .74325 \\
\hline \multirow{2}{*}{ HCT } & $\begin{array}{c}\text { Equal variances } \\
\text { assumed }\end{array}$ & .000 & .992 & .783 & 38 & .439 & 1.07150 & 1.36928 & -1.70046 & 3.84346 \\
\hline & $\begin{array}{c}\text { Equal variances not } \\
\text { assumed }\end{array}$ & & & .783 & 37.700 & .439 & 1.07150 & 1.36928 & -1.70118 & 3.84418 \\
\hline \multirow{2}{*}{ HGB } & $\begin{array}{l}\text { Equal variances } \\
\text { assumed }\end{array}$ & .001 & .969 & -.266 & 38 & .792 & -.08500 & .31932 & -.73144 & .56144 \\
\hline & $\begin{array}{c}\text { Equal variances not } \\
\text { assumed }\end{array}$ & & & -.266 & 37.990 & .792 & -.08500 & .31932 & -.73144 & .56144 \\
\hline \multirow{2}{*}{ PLT } & $\begin{array}{c}\text { Equal variances } \\
\text { assumed }\end{array}$ & .020 & .889 & -.032 & 38 & .975 & -.45000 & 14.19838 & -29.19312 & 28.29312 \\
\hline & $\begin{array}{c}\text { Equal variances not } \\
\text { assumed }\end{array}$ & & & -.032 & 37.945 & .975 & -.45000 & 14.19838 & -29.19450 & 28.29450 \\
\hline \multicolumn{11}{|c|}{ a. group of study = control } \\
\hline
\end{tabular}


Table.4 Comparing values of day 1 and day 7 treatment group

\begin{tabular}{|c|c|c|c|c|c|c|c|c|c|c|}
\hline \multicolumn{11}{|c|}{ Independent Samples Test ${ }^{\text {a day b1 to day } 7}$} \\
\hline & & \multicolumn{2}{|c|}{$\begin{array}{l}\text { Levene's Test for } \\
\text { Equality of Variances }\end{array}$} & \multicolumn{7}{|c|}{ t-test for Equality of Means } \\
\hline & & \multirow{2}{*}{$\mathrm{F}$} & \multirow{2}{*}{ Sig. } & \multirow{2}{*}{$\mathrm{t}$} & \multirow{2}{*}{$\mathrm{df}$} & \multirow{2}{*}{$\begin{array}{c}\text { Sig. } \\
(2- \\
\text { tailed) }\end{array}$} & \multirow{2}{*}{$\begin{array}{l}\text { Mean } \\
\text { Difference }\end{array}$} & \multirow{2}{*}{$\begin{array}{c}\text { Std. } \\
\text { Error } \\
\text { Differenc } \\
\text { e }\end{array}$} & \multicolumn{2}{|c|}{$\begin{array}{l}95 \% \text { Confidence Interval of } \\
\text { the Difference }\end{array}$} \\
\hline & & & & & & & & & Lower & Upper \\
\hline \multirow[b]{2}{*}{$\mathrm{MCHC}$} & Equal variances assumed & .288 & .594 & -.352 & 40 & .727 & -.41857 & 1.18938 & -2.82239 & 1.98525 \\
\hline & $\begin{array}{l}\text { Equal variances not } \\
\text { assumed }\end{array}$ & & & -.352 & $\begin{array}{c}39.98 \\
0\end{array}$ & .727 & -.41857 & 1.18938 & -2.82243 & 1.98529 \\
\hline \multirow[b]{2}{*}{$\mathrm{MCV}$} & Equal variances assumed & .104 & .749 & -.409 & 40 & .684 & -.58095 & 1.41873 & -3.44832 & 2.28642 \\
\hline & $\begin{array}{l}\text { Equal variances not } \\
\text { assumed }\end{array}$ & & & -.409 & $\begin{array}{c}39.77 \\
8\end{array}$ & .684 & -.58095 & 1.41873 & -3.44882 & 2.28692 \\
\hline \multirow[b]{2}{*}{$\mathrm{MCH}$} & Equal variances assumed & .000 & .983 & -.537 & 40 & .595 & -.42571 & .79348 & -2.02939 & 1.17796 \\
\hline & $\begin{array}{c}\text { Equal variances not } \\
\text { assumed }\end{array}$ & & & -.537 & $\begin{array}{c}39.98 \\
9\end{array}$ & .595 & -.42571 & .79348 & -2.02941 & 1.17798 \\
\hline \multirow[b]{2}{*}{ RBCS } & Equal variances assumed & .943 & .337 & .460 & 40 & .648 & .12333 & .26825 & -.41882 & .66549 \\
\hline & $\begin{array}{c}\text { Equal variances not } \\
\text { assumed }\end{array}$ & & & .460 & $\begin{array}{c}39.81 \\
4\end{array}$ & .648 & .12333 & .26825 & -.41890 & .66556 \\
\hline \multirow[b]{2}{*}{$\mathrm{HCT}$} & Equal variances assumed & .271 & .606 & .277 & 40 & .783 & .40571 & 1.46490 & -2.55495 & 3.36638 \\
\hline & $\begin{array}{l}\text { Equal variances not } \\
\text { assumed }\end{array}$ & & & .277 & $\begin{array}{c}39.57 \\
1\end{array}$ & .783 & .40571 & 1.46490 & -2.55595 & 3.36738 \\
\hline \multirow[b]{2}{*}{ HGB } & Equal variances assumed & .078 & .781 & -.075 & 40 & .941 & -.02381 & .31946 & -.66947 & .62185 \\
\hline & $\begin{array}{c}\text { Equal variances not } \\
\text { assumed }\end{array}$ & & & -.075 & $\begin{array}{c}39.84 \\
4 \\
\end{array}$ & .941 & -.02381 & .31946 & -.66955 & .62193 \\
\hline \multirow{2}{*}{ PLT } & Equal variances assumed & .343 & .562 & $\begin{array}{c}- \\
3.784\end{array}$ & 40 & .001 & -55.19063 & 14.58357 & $\begin{array}{c}- \\
84.6651 \\
1\end{array}$ & -25.71614 \\
\hline & $\begin{array}{c}\text { Equal variances not } \\
\text { assumed }\end{array}$ & & & $\begin{array}{c}- \\
3.784\end{array}$ & $\begin{array}{c}39.96 \\
9\end{array}$ & .001 & -55.19063 & 14.58357 & $\begin{array}{c}- \\
84.6658 \\
4\end{array}$ & -25.71542 \\
\hline
\end{tabular}

a.

groupofstudy $=$ treatment 


\section{Int.J.Curr.Microbiol.App.Sci (2021) 10(04): 84-102}

Table.5 Comparing values of day 1 and day 7control group

\begin{tabular}{|c|c|c|c|c|c|c|c|c|c|c|}
\hline \multicolumn{11}{|c|}{ Independent Samples Test $^{\mathrm{a}}$} \\
\hline & & \multicolumn{2}{|c|}{$\begin{array}{c}\text { Levene's Test for } \\
\text { Equality of Variances }\end{array}$} & \multicolumn{7}{|c|}{ t-test for Equality of Means } \\
\hline & & \multirow[t]{2}{*}{$\mathrm{F}$} & \multirow[t]{2}{*}{ Sig. } & \multirow[t]{2}{*}{$\mathrm{t}$} & \multirow[t]{2}{*}{ df } & \multirow{2}{*}{$\begin{array}{l}\text { Sig. }(2- \\
\text { tailed) }\end{array}$} & \multirow{2}{*}{$\begin{array}{c}\text { Mean } \\
\text { Difference }\end{array}$} & \multirow{2}{*}{$\begin{array}{l}\text { Std. Error } \\
\text { Difference }\end{array}$} & \multicolumn{2}{|c|}{$\begin{array}{l}\text { 95\% Confidence Interval of the } \\
\text { Difference }\end{array}$} \\
\hline & & & & & & & & & Lower & Upper \\
\hline \multirow{2}{*}{$\mathrm{MCHC}$} & Equal variances assumed & 1.092 & .303 & $1 . \overline{438}$ & 38 & .159 & -3.47050 & 2.41424 & -8.35788 & 1.41688 \\
\hline & Equal variances not assumed & & & $\begin{array}{c}- \\
1.438\end{array}$ & 22.628 & .164 & -3.47050 & 2.41424 & -8.46929 & 1.52829 \\
\hline \multirow{2}{*}{$\mathrm{MCV}$} & Equal variances assumed & .273 & .604 & -.215 & 38 & .831 & -.32000 & 1.48911 & -3.33455 & 2.69455 \\
\hline & Equal variances not assumed & & & -.215 & 37.652 & .831 & -.32000 & 1.48911 & -3.33547 & 2.69547 \\
\hline \multirow{2}{*}{$\mathrm{MCH}$} & Equal variances assumed & .494 & .486 & $1 . \overline{438}$ & 38 & .159 & -2.10600 & 1.46504 & -5.07181 & .85981 \\
\hline & Equal variances not assumed & & & $\begin{array}{c}- \\
1.438\end{array}$ & 24.148 & .163 & -2.10600 & 1.46504 & -5.12871 & .91671 \\
\hline \multirow{2}{*}{ RBCS } & Equal variances assumed & 2.724 & .107 & .995 & 38 & .326 & .20800 & .20902 & -.21514 & .63114 \\
\hline & Equal variances not assumed & & & .995 & 34.102 & .327 & .20800 & .20902 & -.21673 & .63273 \\
\hline \multirow{2}{*}{ HCT } & Equal variances assumed & .000 & .983 & .722 & 38 & .475 & .98600 & 1.36600 & -1.77932 & 3.75132 \\
\hline & Equal variances not assumed & & & .722 & 37.664 & .475 & .98600 & 1.36600 & -1.78013 & 3.75213 \\
\hline \multirow{2}{*}{ HGB } & Equal variances assumed & 1.783 & .190 & -.943 & 38 & .352 & -.95500 & 1.01260 & -3.00489 & 1.09489 \\
\hline & Equal variances not assumed & & & -.943 & 20.950 & .356 & -.95500 & 1.01260 & -3.06112 & 1.15112 \\
\hline \multirow{2}{*}{ PLT } & Equal variances assumed & .075 & .785 & -.228 & 38 & .821 & -3.25000 & 14.27635 & $\begin{array}{c}- \\
32.15095\end{array}$ & 25.65095 \\
\hline & Equal variances not assumed & & & -.228 & 37.910 & .821 & -3.25000 & 14.27635 & $\begin{array}{c}- \\
32.15320\end{array}$ & 25.65320 \\
\hline \multicolumn{11}{|c|}{ a. groupofstudy = control } \\
\hline
\end{tabular}


The hoof injuries considered the most common hoof affections in working equine in Egypt, and their treatment take a long time before the animal returned to work. The present study aimed to evaluate the efficacy of chitosan in hoof wound healing through clinical, radiographical and haematological examination in addition to observation of the lameness score before and after chitosan and conventional treatment application.

The present study included (41) which suffered from hoof injuries and admitted to Brook hospital in Aswan, where they are divided into two groups. The first group which included (20) were treated with povidone iodine and kept as control. The second group which included (21) were treated with application of chitosan.

White and Moore (1990) reported that, the wounds of hoof heal slowly due to the incidence of contamination, difficulty of hoof wound contraction and inelasticity of the epithelial tissues. Also, Caron (1999) recorded that, the incidence of traumatic wounds is higher in equine than other species and healing usually delayed and complicated.

Wound healing, as a normal biological process in the body, is achieved through four precisely and highly programmed phases: hemostasis, inflammation, proliferation and remodeling (Stadelmann et al., 1998; Uno et al., 1999; Sehn et al., 2009; Tripathi et al., 2009).

Jayasree, Rathinam and Sharma (1995) showed that, Chitosan is one of the bioactive dressing which delivers substances active in wound healing.

Azad, Sermsintham, Chandrkrachang and Stevens (2004) proved that, chitosan provides a non-protein matrix for three dimensions tissue growth and activates macrophages for tumoricidal activity. It stimulates cell proliferation and tissue organization. It will gradually depolymerize to release $\mathrm{N}$-acetyl-bDglucosamine, which initiates fibroblast proliferation and helps in ordered collagen deposition, stimulating increased level of natural hyaluronic acid synthesis at the wound site.

In the present study the local haemostasis was observed after application of chitosan on the wound which indicated that, the haemoststic properties of the chitosan.

The same result was agreed with El-Husseiny et al., (2012) who study the wound healing effect of chitosan application in dogs, where they indicated that, hemostasis property of chitosan was directly observed in all treated animals which is considered beneficial in accidental bleeding wounds and could act as a hemostatic dressing as well as for wound healing.

Also, the present results agreed with Okamoto et al., (1995); Mizuno et al., (2003) who reported that, the application of chitosan to the open wounds in dogs induced exudate which has a high growth factor activity, and induced infiltration by inflammatory cells and granulation tissue formation accompanied by angiogenesis.

The local application of chitosan assists in increased blood flow and elimination of infection due to its antibacterial effect (Batrone and Adickes, 1988).

In the present study, all treated animals with chitosan showed no pus exudates. While, 6 cases in control group were infected and showed pus discharge and this indicates the antimicrobial nature of chitosan. The same result was indicated by Qi (2004); Paz (2011) they reported that, chitosan exhibits a wide range of antimicrobial activity against bacteria, filamentous fungi, yeast and even 
virus. Studies have reported antibacterial activity of chitosan against Escherichia coli, Staphylococcus aureus, Streptococcus mutans, Salmonella, typhimurium, Salmonella choleraesuis, and Pseudomonas aeruginosa.

The infection is the most common factor which delay the wound healing in equine, the same result was indicated by Hendrickson (2012); Metwally et al., (2020).

In our study, significance increase in PLT in animals treated with chitosan compared with control group and that explain the good result of stop bleeding on treatment group of animals. Also the previous result agreed with Abou El Ella et al., (2007) as they proved that, chitosan enhanced the haemostatic effect through striking increase of platelets count which reflected on the marked reduction of PT and APPT. Also, Okomoto et al., (2003) recorded that, chitosan make aggregation of platelets which clearly revealed on decreasing of blood coagulation time.

In the present study, the most cases of hoof wound were present in the forelimb the results was also recorded by Ragab et al., (2010) who recorded that the prevalence of hoof injuries were most commonly affecting the forelimb of equine.

From the radiographic study recorded in the paper, the wound of the hoof and/or surrounding structures appeared as lysis of the hoof horny tissues and soft tissues with loss of radiographic densities. After treatment the tissues returned to its normal radiographic densities the same results was also recorded by Abou El Ella et al., (2007).

Lastly, we can conclude that, chitosan is one of bioactive materials which assists and accelerates the healing of the hoof injuries. Using of topical chitosan as dry material in equine hoof abscess accelerates the rate of hoof wound healing in addition to its antimicrobial effect when compared with conventional treatment.

\section{Acknowledgment}

The authors would thank Dr. Asmaa A. Metwally, Lecturer of Surgery, Anaesthesiology and Radiology, Faculty of Veterinary Medicine, Aswan University, Egypt for her help in interpretation of X-ray films, writing and revision of the manuscript.

\section{References}

Abdel-hady, A., Sadan, M., Metwally, A. A. \& Soliman, A. 2017. Clinico-radiographic Studies on The Prevalent Distal Limb Affections in Working Equine at Luxor City. Journal of Advanced Veterinary Research, 7, 24-32.

Abou-El-Ella, A. G., Fathhlla, A. I., AbedelRahman, H. A., Minami, S. 2007. Effects of chitosan on experimental frog wound healing in donkeys (Equisasinus) and associated changes of hematological and histological profiles. Vet. Med. J. Giza, 55(1): 67-86.

Balassa, L. \& Prudden, J. Applications of chitin and chitosan in wound-healing acceleration. Proceedings of the first international conference on chitin/chitosan, 1978. National Technical Information: Spring field, VA, 296-305.

Bartone, F. F. and Adickes, E. (1988): Chitosan: effects on wound healing in urogenital tissues: Preliminary report. J Urol., 140: 1134- 1137.

Baxter, G. \& turner, A. 2002. Diseases of bone and related structures, Adams' lameness, Stashak T S ed, 401-457. Lippincott Williams \& Wilkins, Philadelphia.

Caron JP. Management of superficial wounds. In: Equine Surgery, 2nd Edit., PA Philadelphia, Saunders; 1999. pp.129-140

Constantinescu, G. M. \& Constantinescu, I. A. 2013. The Updated International Veterinary Anatomical and Embryological Nomenclatures. J Vet Sci AnimHusb, 1, 
e201.

Dabareiner, R. M. \& carter, G. K. 2003. Diagnosis, treatment, and farriery for horses with chronic heel pain. The Veterinary clinics of North America. Equine practice, 19, 417-441.

Grundmann, I., Drost, W. T., Zekas, L. J., Belknap, J. K., Garabed, R., Weisbrode, S., Parks, A., Knopp, M. \& Maier L, J. 2015. Quantitative assessment of the equine hoof using digital radiography and magnetic resonance imaging. Equine veterinary journal, 47, 542-547.

Hendrickson, D. A. (2012). Management of superficial wounds. Equine surgery. Elsevier

Inas, N. \& Kawkab, A. 2012. Application of chitosan for wound repair in dogs. Life Science Journal, 1, 2201

L. E. C. de Paz, A. Resin, K. A. Howard, D. S. Sutherland, and P. L. Wejse, Appl. Environ. Microbiol., 77, 3892 (2011).

L. Qi, Z. Xu, X. Jiang, C. Hu, and X. Zou, Carbohydr.Res., 339, 2693 (2004).

Metwally, A., Abdel-hady, A.-N. A., Ebnalwaled, K., Morad, S. A. \& Soliman, A. A. 2020. Wound-Healing Activity of Green and Chemical Zinc Oxide Nanoparticles (ZnONPs) Gels in Equine Wounds: A clinical Study. SVU-International Journal of Veterinary Sciences, 3, 66-79.

Mizuno K, Yamamura K, Yano K, et al., Effect of chitosan film containing basic fibroblast growth factor on wound healing in genetically diabetic mice. Journal of Biomedical Materials Research A, 2003; 64:177-181.

Okamoto K, Sibazaki S, Minami A, Matsuhashi S,
Tanioka Y, Shigemasa Y. Evaluation of chitin and chitosan on open wound healing in dogs. Journal of Veterinary Medical Science, 1995; 57:851-854.

Okomoto, Y. ; Yano, R.; Miyatake, K.; Tomohiro, I.; Shigemasa, Y. and Minami, S. (2003): Effects of chitin and chitosan on blood coagulation. Carbohydrate polymers, 53: 337- 342 .

Paul, W. \& Sharma, C. P. 2004. Chitosan and alginate wound dressings: a short review. Trends Biomater Artif Organs, 18, 18-23.

Ragab, G, seif, M., sedeek, M. \&fathy, M. 2010. Incidence of hoof affections in equine. Bs. Vet. Med. J., 20, 19-29.

Sehn E, Hernandes L, Franco S, Gonçalves C C $\mathrm{M}$, Baesso $\mathrm{M}$. Dynamics of reepithelisation and penetration rate of a bee propolis formulation during cutaneous wounds healing. Analytica chimica acta. 04/01 2009;635:115-120.

Stadelmann W K, Digenis A G, Tobin G R. Physiology and healing dynamics of chronic cutaneous wounds. American journal of surgery. Aug 1998;176(2A Suppl):26s-38s.

Tripathi, S., Mehrotra, G. K., \& Dutta, P. K. (2009). Preparation and physico-chemical evaluation of chitosan/poly(vinyl alcohol)/pectin ternary film for foodpackaging applications. Carbohydrate Polymers, 79, 711-716.

Uneo, H.; Mori, T. and Fujinaga, T. (2001): topical formulation and wound healing applic

White N. A. and Moore J.N. (1990): Current practice of equine surgery. J.P. Lippincott Company, Philadelphia.

\section{How to cite this article:}

Ahmed Mohamed Abdou, Azab, Abdelnaser Abdelmoneim and Soliman, Ahmed Sayed. 2021. Efficacy of Chitosan as a Dry Dressing for Treatment of Open Hoof Wounds. Int.J.Curr.Microbiol.App.Sci. 10(04): 84-102. doi: https://doi.org/10.20546/ijcmas.2021.1004.009 